\title{
Clinical Profile of Thyroid Disorders - A retrospective study at BPKIHS
}

\author{
Anuskha Agrawal ${ }^{1}$, Nidhi Rani ${ }^{1}$, Robin Maskey ${ }^{2}$ \\ ${ }^{1}$ Undergraduate Students, ${ }^{2}$ Additional Professor, Department of Internal Medicine, B.P. Koirala Institute \\ of Health Sciences, Dharan, Nepal
}

\begin{abstract}
Background: The thyroid gland produces two key metabolic hormones which regulate metabolic rate, growth and development. They play vital roles in digestion, heart and muscle function, brain development and maintenance of bones. People suffering from thyroid disorders may have autoimmune disease, ranging from primary hypothyroidism, Hashimoto's thyroiditis, to hyperthyroidism caused by Graves' disease.

Objectives: To study clinical profile of thyroid disorders in endocrinology clinic of BPKIHS, Nepal. Methods: This is a hospital based retrospective study of past five years (2012 - 2017) done in department of internal medicine at B.P. Koirala Institute of Health Sciences, in which thyroid disorder patient records from the endocrinology clinic will be compiled together will be analyzed after classifying them according to the guidelines of the American Thyroid Association (ATA). Results: Among 584 thyroid disorder cases that were sampled, higher prevalence of thyroid disorders was seen in females, and the Male: Female ratio was 1:4.13. Most common type of thyroid disorder was Hypothyroidism (29.6\%) followed by Subclinical hypothyroidism (28.3\%).

Conclusions: Thyroid disorders are more common in females than males and hypothyroidism being commonest thyroid disorder in our setup. Subclinical hypothyroidism is second commonest followed by hyperthyroidism. In Subclinical hypothyroidism Anti TPO antibody is most commonly found to be positive.
\end{abstract}

Key Words: Hypothyroidism, Hyperthyroidism, Thyroid disorder

\section{Introduction}

The thyroid gland produces two key metabolic hormones viz. thyroxine (T4) and tri-iodothyronine (T3). ${ }^{1}$ These hormones regulate metabolic rate, growth and development. The thyroid disorders include hypothyroidism, subclinical hypothyroidism, hyperthyroidism, subclinical hyperthyroidism and Secondary hypothyroidism. ${ }^{2}$ Their clinical manifestations vary considerably from area to area and are determined principally by availability of iodine in the diet. ${ }^{3}$

Corresponding Address: Anushka Agrawal, MBBS Student B.P.Koirala Institute of Health SciencesTelephone No.: 9813162074,Email: bestofanushka@gmail.com
According to WHO, about 31\% (1 900.9 million) of the world's population is estimated to have insufficient iodine intakes, with the most affected WHO regions being South-East Asia and Europe., ${ }^{4,5}$ Within South-East Asia, Nepal is a mountainous landlocked country, which due to its geographical placement and high annual rainfall, has very low soil iodine content. This leads to an ever increasing number of iodine deficiency disorders and thyroid dysfunction in the general population. ${ }^{6,7}$

Though the clinical profile of thyroid dysfunction has previously been studied in other parts of Nepal, to the best of our knowledge, this is the first study to be reported from the eastern part of Nepal. The 
objective of this study is to assess the clinical profile of thyroid disorder in the eastern region of Nepal.

\section{Methodology}

This is a Hospital based retrospective cross sectional study done in Endocrinology clinic, Department of Internal Medicine, BPKIHS. Since this is a hospital based retrospective study of the medical records of thyroid disorders patients, presenting to the endocrinology clinic of BPKIHS in the past five years (2012-2017), so all the diagnosed cases of thyroid disorders of that duration will be taken as the sample size.

The Inclusion Criteria were all diagnosed case of thyroid disorders as per ATA guidelines visiting endocrinology clinic at BPKIHS were selected irrespective of age and sex.

The thyroid disorder patient records from the endocrinology clinic will be compiled together after permission from the institutional ethical committee. The records collected will be analyzed after classifying them according to the guidelines of the American Thyroid Association (ATA).

ATA/AACE guidelines 2011 (Bahn et al, 2011)

a.Primary Hyperthyroidism: There is constitutive activation of thyroid hormone synthesis \& secretion leading to autonomous release of excess thyroid hormone. Raised FT3, FT4 and decreased TSH levels.

b. Secondary Hyperthyroidism: Occurs if thyroid is inappropriately stimulated by tropic factors. Decreased FT3, FT4 and raised TSH levels.

c.Subclinical Hyperthyroidism: Low or undetectable TSH with values within the normal reference range for both $\mathrm{T} 3$ and $\mathrm{T} 4$ estimates.

d.Graves' disease: Graves' disease is an autoimmune disorder. Thyrotropin receptor antibodies stimulate the TSH receptor, increasing thyroid hormone production.

e.Sub-acute Thyroiditis: Sub-acute thyroiditis is thought to be caused by viral infection and is characterized by fever and thyroid pain.

f. Euthyroid: Normal FT3, FT4 \& TSH levels.
g.Hypothyroidism: Decreased FT3 and FT4 level and increased TSH level.

h.Had no change: FT3, FT4 and TSH value before and after the treatment has no significant change.

i. Graves Ophthalmopathy: Graves Ophthalmopathy is an inflammatory eye disease that develops in the orbit in association with autoimmune thyroid disorders.

TFT via immunofluorescence method (CLIA) was : FT3: 1.21 to $4.18 \mathrm{picogm} / \mathrm{ml}$

FT4: 8.9 to $17.2 \mathrm{picogm} / \mathrm{ml}$

TSH: 0.3 to $4.5 \mathrm{micro} \mathrm{IU} / \mathrm{ml}$

\section{Results}

Table 1: Age distribution of the sampled thyroid patients $(n=584)$

\begin{tabular}{|c|c|c|}
\hline $\begin{array}{c}\text { Age Group } \\
\text { ( in years })\end{array}$ & Frequency & Percentage \\
\hline $15-30$ & 175 & 30.0 \\
\hline $31-45$ & 237 & 40.6 \\
\hline $46-60$ & 148 & 25.3 \\
\hline $60-75$ & 19 & 3.3 \\
\hline$>75$ & 5 & 0.9 \\
\hline Total & $\mathbf{5 8 4}$ & 100.0 \\
\hline
\end{tabular}

Table 1 above shows that out of the total 584 thyroid disorder cases that were sampled, higher prevalence of thyroid disorders was seen in the age group 31-45. 
Table 2: Sex distribution of the sampled thyroid patients $(n=584)$

\begin{tabular}{|c|c|c|}
\hline Sex & Frequency & Percentage \\
\hline Female & 470 & 80.5 \\
\hline Male & 114 & 19.5 \\
\hline Total & $\mathbf{5 8 4}$ & $\mathbf{1 0 0 . 0}$ \\
\hline
\end{tabular}

Table 2 above shows that out of the total 584 thyroid disorder cases that were sampled, higher prevalence of thyroid disorders was seen in females, and the Male: Female ratio was 1:4.13.

Table 3: Thyroid Disorder distribution of sampled thyroid patients $(n=584)$

\begin{tabular}{|c|c|c|}
\hline Thyroid disorder & Frequency & Percentage \\
\hline $\begin{array}{c}\text { Hypothyroidism } \\
\text { Hypothyroidism } \\
\text { Subclinical }\end{array}$ & 173 & 29.6 \\
\hline Euthyroidism & 28 & 28.3 \\
\hline $\begin{array}{c}\text { Hyperthyroidism } \\
\text { Subclinical } \\
\text { Hyperthyroidism }\end{array}$ & 19 & 13.7 \\
\hline $\begin{array}{c}\text { Secondary } \\
\text { Hypothyroidism }\end{array}$ & 53 & 9.1 \\
\hline $\begin{array}{c}\text { Others (Thyroiditis, } \\
\text { Goitre) }\end{array}$ & 20 & 3.4 \\
\hline $\begin{array}{c}\text { Sick Euthyroid } \\
\text { Syndrome }\end{array}$ & 46 & 7.9 \\
\hline \begin{tabular}{c} 
Total \\
\hline
\end{tabular} & 584 & 100.0 \\
\hline
\end{tabular}

Table 3 above shows that out of the total 584 thyroid disorder cases that were sampled, most common type of thyroid disorder was Hypothyroidism (29.6\%) followed by Subclinical hypothyroidism $(28.3 \%)$.
Table 4: Distribution of Anti TPO Antibody test results of sampled thyroid patients $(n=584)$

\begin{tabular}{|c|c|c|}
\hline $\begin{array}{c}\text { Anti TPO } \\
\text { Antibody }\end{array}$ & Frequency & Percentage \\
\hline Not Tested & 293 & 50.2 \\
\hline Negative (<30) & 99 & 17.0 \\
\hline Positive (>30) & 192 & 32.9 \\
\hline Total & $\mathbf{5 8 4}$ & $\mathbf{1 0 0 . 0}$ \\
\hline
\end{tabular}

Table 4 above shows that out of the total 584 thyroid disorder cases that were sampled, 293 patients were not tested for Anti TPO Antibody. Among the 291 tested patients, 99 tested negative, i.e. $<30$ and 192 tested positive, i.e. $>30$.

Table 5: Thyroid disorder distribution in Anti TPO Antibody positive patients $(n=192)$

\begin{tabular}{|c|c|c|}
\hline Thyroid disorder & Frequency & Percentage \\
\hline Hypothyroidism & 53 & 27.6 \\
\hline $\begin{array}{c}\text { Subclinical } \\
\text { Hypothyroidism }\end{array}$ & 55 & 28.6 \\
\hline Euthyroidism & 6 & 3.1 \\
\hline $\begin{array}{c}\text { Hyperthyroidism } \\
\begin{array}{c}\text { Subclinical } \\
\text { Hyperthyroidism }\end{array}\end{array}$ & 3 & 15.8 \\
\hline $\begin{array}{c}\text { Secondary } \\
\text { Hypothyroidism }\end{array}$ & 28 & 14.6 \\
\hline $\begin{array}{c}\text { Others (Thyroiditis, } \\
\text { Goitre) }\end{array}$ & 7 & 3.6 \\
\hline $\begin{array}{c}\text { Sick Euthyroid } \\
\text { Syndrome }\end{array}$ & 25 & 13.0 \\
\hline \begin{tabular}{c} 
Total \\
\hline
\end{tabular} & 192 & 100.0 \\
\hline
\end{tabular}

Table 5 above shows that out of the total 192 thyroid disorder cases that tested positive for Anti TPO Antibody test, most common type of thyroid disorder was Subclinical Hypothyroidism (28.6\%) followed by Hypothyroidism (27.6\%). 
Table 6: Differences in the characteristics of all thyroid disorder patients who underwent testing for Anti TPO Antibody $(n=291)$

\begin{tabular}{|l|l|l|l|l|}
\hline & \multicolumn{1}{|c|}{ Negative } & \multicolumn{1}{|c|}{ Positive } & \multicolumn{1}{|c|}{ Total } & Value \\
\hline Age & & & & \\
$15-30$ & $35(35.4 \%)$ & $55(28.6 \%)$ & 90 & \\
$31-45$ & $41(41.4 \%)$ & $79(41.1 \%)$ & 120 & \\
$46-60$ & $20(20.2 \%)$ & $54(28.1 \%)$ & 74 & 0.250 \\
$60-75$ & $2(2.0 \%)$ & $4(2.1 \%)$ & 6 & \\
$>75$ & $1(1.0 \%)$ & $0(0.0 \%)$ & 1 & \\
\hline Sex & $78(78.8 \%)$ & $155(80.7 \%)$ & 233 & 0.695 \\
Female & $21(21.2 \%)$ & $37(19.3 \%)$ & 58 & \\
Male & & & & \\
\hline Type of Thyroid & $24(24.2 \%)$ & $53(27.6 \%)$ & 77 & \\
Hypothyroidism & $26(26.3 \%)$ & $55(28.6 \%)$ & 81 & \\
Subclinical Hypothyroidism & $12(12.1 \%)$ & $6(3.1 \%)$ & 18 & \\
Euthyroidism & $6(6.1 \%)$ & $15(7.8 \%)$ & 21 & 0.791 \\
Hyperthyroidism & $6(6.1 \%)$ & $3(1.6 \%)$ & 9 & \\
Subclinical Hyperthyroidism & $28(14.6 \%)$ & 40 & \\
Secondary Hypothyroidism & $12(12.1 \%)$ & $7(3.6 \%)$ & 10 & \\
Others (Thyroiditis, Goitre) & $3(3.0 \%)$ & $75(13.0 \%)$ & 35 & \\
Sick Euthyroid Syndrome & $10(10.1 \%)$ & $25(19 \%)$ & $\mathbf{2 9 1}$ & \\
\hline Total & $\mathbf{9 9}$ & $\mathbf{1 9 2}$ & \\
\hline
\end{tabular}

Table 6 above shows that out of 291 Thyroid disorder patients who were tested for Anti TPO Antibody, differences were seen in the characteristics for those who tested positive and negative. Among the most common age group, i.e. 31 - 45 , almost equal distribution ( $41.4 \%$ for negative and $41.1 \%$ for positive) can be seen. Between sex distribution, the male: female ratio for negative and positive tested were approximately 3:11 and 4:17 respectively. For people tested for the antibody, the most common type of thyroid was Subclinical Hypothyroidism, whose distribution slightly varies with $26.3 \%$ for negative and $28.6 \%$ for positive tested. 
Table 7: Association between Type of Thyroid Disorders and Age group of sample size

$$
(\mathrm{n}=584)
$$

\begin{tabular}{|c|c|c|c|c|c|c|c|}
\hline \multirow{2}{*}{ Type of Thyroid } & \multicolumn{5}{|c|}{ Age } & \multirow{2}{*}{ Total } & \multirow{2}{*}{$P$ value } \\
\hline & $15-30$ & $31-45$ & $46-60$ & $60-75$ & $>75$ & & \\
\hline Hypothyroidism & $\begin{array}{c}51 \\
(29.5 \%) \\
\end{array}$ & $\begin{array}{c}69 \\
(39.9 \%) \\
\end{array}$ & $\begin{array}{c}46 \\
(26.6 \%) \\
\end{array}$ & $\begin{array}{c}6 \\
(3.5 \%)\end{array}$ & $\begin{array}{c}1 \\
(0.6 \%)\end{array}$ & 173 & \multirow{9}{*}{0.535} \\
\hline $\begin{array}{c}\text { Subclinical } \\
\text { Hypothyroidism }\end{array}$ & \begin{tabular}{|c|}
55 \\
$(33.3 \%)$ \\
\end{tabular} & $\begin{array}{c}61 \\
(37.0 \%) \\
\end{array}$ & $\begin{array}{c}41 \\
(24.8 \%) \\
\end{array}$ & $\begin{array}{c}6 \\
(3.6 \%)\end{array}$ & $\begin{array}{c}2 \\
(1.2 \%)\end{array}$ & 165 & \\
\hline Euthyroidism & $\begin{array}{c}9 \\
(32.1 \%) \\
\end{array}$ & $\begin{array}{c}10 \\
(35.7 \%) \\
\end{array}$ & $\begin{array}{c}8 \\
(28.6 \%) \\
\end{array}$ & $\begin{array}{c}0 \\
(0.0 \%)\end{array}$ & $\begin{array}{c}1 \\
(3.6 \%)\end{array}$ & 28 & \\
\hline Hyperthyroidism & $\begin{array}{c}24 \\
(30.0 \%) \\
\end{array}$ & $\begin{array}{c}27 \\
(33.8 \%) \\
\end{array}$ & $\begin{array}{c}25 \\
(31.3 \%) \\
\end{array}$ & $\begin{array}{c}3 \\
(3.8 \%)\end{array}$ & $\begin{array}{c}1 \\
(1.3 \%)\end{array}$ & 80 & \\
\hline $\begin{array}{c}\text { Subclinical } \\
\text { Hyperthyroidism }\end{array}$ & \begin{tabular}{|c|}
4 \\
$(21.1 \%)$ \\
\end{tabular} & $\begin{array}{c}8 \\
(42.1 \%) \\
\end{array}$ & $\begin{array}{c}6 \\
(31.6 \%)\end{array}$ & $\begin{array}{c}1 \\
(5.3 \%)\end{array}$ & $\begin{array}{c}0 \\
(0.0 \%)\end{array}$ & 19 & \\
\hline $\begin{array}{c}\text { Secondary } \\
\text { Hypothyroidism }\end{array}$ & $\begin{array}{c}11 \\
(20.8 \%)\end{array}$ & $\begin{array}{c}30 \\
(56.6 \%)\end{array}$ & $\begin{array}{c}12 \\
(22.6 \%)\end{array}$ & $\begin{array}{c}0 \\
(0.0 \%)\end{array}$ & $\begin{array}{c}0 \\
(0.0 \%)\end{array}$ & 53 & \\
\hline $\begin{array}{c}\text { Others } \\
\text { (Thyroiditis, Goitre) }\end{array}$ & $\begin{array}{c}6 \\
(30.0 \%)\end{array}$ & $\begin{array}{c}11 \\
(55.0 \%)\end{array}$ & $\begin{array}{c}2 \\
(10.0 \%)\end{array}$ & $\begin{array}{c}1 \\
(5.0 \%)\end{array}$ & $\begin{array}{c}0 \\
(0.0 \%)\end{array}$ & 20 & \\
\hline $\begin{array}{l}\text { Sick Euthyroid } \\
\text { Syndrome }\end{array}$ & $\begin{array}{c}15 \\
(32.6 \%)\end{array}$ & $\begin{array}{c}21 \\
(45.7 \%)\end{array}$ & $\begin{array}{c}8 \\
(17.4 \%)\end{array}$ & $\begin{array}{c}2 \\
(4.3 \%)\end{array}$ & $\begin{array}{c}0 \\
(0.0 \%)\end{array}$ & 46 & \\
\hline Total & \begin{tabular}{|c|}
175 \\
$(30.0 \%)$
\end{tabular} & $\begin{array}{c}237 \\
(40.6 \%)\end{array}$ & $\begin{array}{c}148 \\
(25.3 \%)\end{array}$ & $\begin{array}{c}19 \\
(3.3 \%)\end{array}$ & $\begin{array}{c}5 \\
(0.9 \%)\end{array}$ & 584 & \\
\hline
\end{tabular}

Table 7 above shows the association between type of thyroid disorders and age group, which has turned to be not significant $(\mathrm{P}>0.05)$. 
Table 8: Association between Type of Thyroid Disorders and Sex of sample size $(n=584)$

\begin{tabular}{|c|c|c|c|c|}
\hline \multirow{2}{*}{ Type of Thyroid } & \multicolumn{2}{|c|}{ Age } & \multirow{2}{*}{ Total } & \multirow{2}{*}{ P Value } \\
\hline & Male & Female & & \\
\hline Hypothyroidism & $143(82.7 \%)$ & $30(17.3 \%)$ & 173 & \multirow{8}{*}{0.162} \\
\hline Subclinical Hypothyroidism & $139(84.2 \%)$ & $26(15.8 \%)$ & 165 & \\
\hline Euthyroidism & $22(78.6 \%)$ & $6(21.4 \%)$ & 28 & \\
\hline Hyperthyroidism & $57(71.3 \%)$ & $23(28.8 \%)$ & 80 & \\
\hline Subclinical Hyperthyroidism & $14(73.7 \%)$ & $5(26.3 \%)$ & 19 & \\
\hline Secondary Hypothyroidism & $43(81.1 \%)$ & $10(18.9 \%)$ & 53 & \\
\hline Others (Thyroiditis, Goitre) & $18(90.0 \%)$ & $2(10.0 \%)$ & 20 & \\
\hline Sick Euthyroid Syndrome & $34(73.9 \%)$ & $12(26.1 \%)$ & 46 & \\
\hline Total & $470(80.5 \%)$ & $114(19.5 \%)$ & 584 & \\
\hline
\end{tabular}

Table 8 above shows the association between type of thyroid disorders and sex distribution, which has turned to be not significant $(\mathrm{P}>0.05)$.

\section{Discussion}

The study was done in B. P. Koirala Institute of Health Sciences of Dharan in the Eastern region of Nepal. All diagnosed cases of thyroid disorders as per ATA guidelines visiting endocrinology clinic at BPKIHS were selected irrespective of age and sex. From our study, we found that maximum $(80 \%)$ of the patients suffering from thyroid disorders are females. Our result was similar to all other surveys done in different parts of the country as well as outside the country. $8,9,10,11,12$

From our study, we found that the most common age group for thyroid disorders is $31-45$ (40.6\%), which was similar to the data obtained in Lumbini
Medical College Teaching Hospital (LMCTH), where the mean age for males was 39.28 years $(\mathrm{SD}=19.01)$ and that of female was 39.60 years $(\mathrm{SD}=14.63) .{ }^{11}$ The results from other studies varied slightly. In Charak Hospital, Pokhara higher prevalence was observed in the subjects whose ages were above 41-50 years.8 In Shree Puspanjali Hospital Pvt. Ltd, Bharatpur-10, mean age was 45.9 \pm 1.3 years.9 In Malankara Orthodox Syrian Church Medical College, in Kerala State, the highest proportion of cases was reported in 40-60 years.10 In Benazer Bhutto Hospital, Islamabad, the study showed that young adult in the range of 16-40 years are more likely to suffer from thyroid illness. $^{12}$ 
From our study, we found that the most common type of thyroid disorder is Hypothyroidism (29.6\%) followed by Subclinical hypothyroidism (28.3\%), which was similar but less than that found in Shree Puspanjali Hospital Pvt. Ltd, Bharatpur-10, which was $87 \% 9$ and in Benazer Bhutto Hospital, Islamabad, which was $63 \% .^{12}$ Whereas in Charak Hospital, Pokhara, Subclinical hypothyroidism $(10.50 \%)$ had higher prevalence, ${ }^{8}$ in Lumbini Medical College Teaching Hospital (LMCTH), Euthyroid cases were $76.7 \%{ }^{11}$ and in Malankara Orthodox Syrian Church Medical College, in Kerala State, most commonly observed type of thyroid disorder was Non-toxic multinodular goiter $(48.5 \%){ }^{10}$

\section{Conclusion}

Thyroid disorders are more common in females than males and hypothyroidism being commonest thyroid disorder in our setup. Subclinical hypothyroidism is second commonest followed by hyperthyroidism. In Subclinical hypothyroidism Anti TPO antibody is most commonly found to be positive.

\section{REFERENCES}

1. Phillips JA. Thyroid hormone disorder/released May 2001. Available from: http://www.csa.com/ discovery guides/thyroid/overview.php [cited on 2010 Jun].

2. Zimmerman MB. Iodine deficiency. Endocr Rev 2009; 30:376-408.

3. Mark P.J. Vanderpum. Epidemiology of thyroid disease and swelling. In:John A.H. Wass. Editors. Oxford Textbook of Endocrinology and Diabetes. 2nd edn. Oxford University Press: 2011.10.1093/ $\mathrm{med} / 9780199235292.003 .307410$.

4. Vanderpump MP. The epidemiology of thyroid diseases. In: Braverman LE, Utiger RD, editors. Wesner and Ingbar's the Thyroid: A Fundamental and Clinical Text. 9th ed. Philadelphia: JB Lippincott-Raven; 2005. p. 398-496.

5. International Council for Control of Iodine
Deficiency Disorders., UNICEF. World Health Organization. Assessment of iodine deficiency disorders and monitoring their elimination: a guide for programme managers. 2nd. Geneva: World Health Organization; 2001.

6. Baral N, Lamsal M, Koner BC, Koirala S. Thyroid dysfunction in eastern Nepal. Southeast Asian J Trop Med Public Health. 2002;33:63841. [PubMed].

7. Brownlie BE, Wells JE. The epidemiology of thyrotoxicosis in New Zealand: incidence and geographical distribution in north Canterbury, 1983-1985. Clin Endocrinology. 1990;33:24959.[PubMed].

8. Yadav RK, Magar NT, Poudel B, Yadav NK, Yadav B. A Prevalence of Thyroid Disorder in Western Part of Nepal. Journal of Clinical and Diagnostic Research: JCDR. 2013;7(2):193196.

9. Adhikari BR, Twayana RS, Shrestha S, Vaidya N, Aghrahari M, Ghimire B. Pattern of thyroid disorders in people from central Nepal: A Hospital based study. International Journal of Scientific and Research Publications, 2017; 7 (8): 132-36.

10.Antony J, Celine T M, Chacko M. Spectrum of thyroid disorders: A retrospective study at a medical college hospital. Thyroid Res Pract 2014;11:55-9.

11.Raj Krishna Dangol, Priya Lanjekar, Chandrashekhar Pulipati. Thyroid Function Abnormalities among Hospital Patients of Hilly Nepal. Journal of Lumbini Medical College. 2017; 5 (1).

12.Rubina Mansoor et al. Spectrum of Thyroid Diseases, An Experience in the Tertiary care and Teaching Hospital. Ann. Pak. Inst. Med. Sci. 2010; 6(2): 101-106. 